\title{
Boendesegregationens utveckling och konsekvenser
}

\author{
MARIA KÖLEGÅRD STJÄRNE, JOHAN FRITZELL, LARS \\ BRÄNNSTRÖM, FELIPE ESTRADA \& ANDERS NILSSON
}

Boendesegregationen har under senare tid alltmer setts som en central samhällsfräga. I denna artikel analyseras hur den socioekonomiska segregationen har utvecklats under senare decennier och här diskuteras vidare vilka teoretiska ansatser och förklaringar som använts inom forskningen för att förstå hur platsen där man bor kan vara viktigför individers välfärd.

I många länder tycks det finnas en oro för en utveckling där olika bostadsområden skiljer sig allt tydligare med avseende på de boendes socioekonomiska resurser

Maria Kölegård Stjärne, Med.dr., epidemiolog, Centrum för forskning om ojämlikhet i hälsa (CHESS), Stockholms universitet/Karolinska institutet, Stockholm.

Johan Fritzell, professor i sociologi, Centrum för forskning om ojämlikhet i hälsa (CHESS), Stockholms universitet/Karolinska institutet \& Institutet för framtidsstudier, Stockholm.

Lars Brännström, fil.dr. i sociologi, Socialstyrelsen, Stockholm.

Felipe Estrada, docent i kriminologi, Brottsförebyggande rådet (BR $\AA$ ), Stockholm.

Anders Nilsson, docent i kriminologi, Institutet för framtidsstudier, Stockholm. och etniska sammansättning (Andersson 2000, Buck 2001, Musterd 2005). Begreppet segregation har hamnat i fokus för samhällsdebatten. Levnadsförhållandena, ofta beskrivna i termer av "social exkludering" eller "utanförskap», i de fattigaste och socialt mest utsatta bostadsområdena är idag också en central politisk fråga (Palander 2006). Segregation är dock inte nytt som samhällsproblem:

„Ord som 'utslagning', 'utstötning', 'utklassning' och 'segregation ' harpå senare år blivit allt vanligare $i$ den aktuella samhällsdebatten $i$ Sverige. Ibland undrar man om detta beror på någon modebetonad jargong. Är det kanske samma gamla problem som pre- 
senteras $i$ ny språklig skrud eller har samhällsproblemen bytt karaktär" (Berglind 1974 s. 47).

Det som drygt 30 år efter Berglinds studie är slående är hur liten kunskapen faktiskt är om de konsekvenser segregationen har för människors livschanser och levnadsförhållanden. Som flera påpekat under senare tid har den svenska forskningen i mycket liten utsträckning studerat effekter av områdesförhållanden (Andersson 2000, Stjärne 2005, Brännström 2006). Också kunskapen om boendesegregationens förändringar och trender är mager om vi jämför med andra forskningsfält (men se Andersson 2000, Socialstyrelsen 2006). I denna artikel intresserar vi oss för dessa frågor men ska också ta upp en rad mer begreppsliga, metodologiska och teoretiska problem, utan vilka analyser om segregationen och områdes- eller grannskapseffekter knappast blir begripliga. De övergripande frågeställningarna är: 1) Vilka förklaringar har framförts kring varför och hur bostadsområdet kan påverka individuella utfall? 2) Hur har den socioekonomiska boendesegregationen i Sverige utvecklats? 3) Vilken kunskap finns kring bostadsområdets effekter på olika välfärdsförhållanden?

Segregation kan till viss del ses som det rumsliga uttrycket för ojämlikhet och den första övergripande frågan vi ställer rör vilka teorier och förklaringsmodeller som använts i forskningen kring hur människors livsvillkor påverkas av var man bor. Till viss del är det självfallet så att förklaringar är specifika för de utfall vi studerar; om vi vill studera varför personer i vissa områden läser vidare i högre utsträckning verkar det rimligt att förklaringarna är annorlunda än om vi vill förklara varför (andra) personer löper högre risk att få en viss sjukdom. Som vi ska se är det dock i relativ stor utsträckning samma övergripande, generella »teoriansatser» som använts i forskningen för att förklara olika väsensskilda utfall.

Den andra övergripande frågan vi ska belysa är hur boendesegregationens utveckling ser ut i Sverige. Utöver att kort sammanfatta tillgänglig kunskap om etnisk boendesegregation kommer vi att presentera nya analyser av den socioekonomiska boendesegregationen i Sverige åren 1980, 1990 och 2000. Att discipliner som sociologi i grund och botten handlar om hur våra liv påverkas av den sociala omgivningen i bred bemärkelse gör frågan om omgivningseffekter naturlig. Boendesegregationens eventuella betydelse är intimt förknippad med forskning om så kallade grannskaps-/ områdeseffekter, eller mer allmänt kontextuella effekter. Vad man då försöker analysera är om platsen där man bor spelar någon roll efter det att vi tagit hänsyn till individernas egna sociala karakteristika. Det är denna eventuella effekt som ofta benämns kontextuell (se vidare nedan). Den tredje övergripande frågeställningen behandlar på så vis konsekvenser av segregation på människors livschanser (också bokstavligt talat) och levnadsförhållanden. Vi har valt att utgå från tre centrala, men samtidigt disparata, välfärdsdimensioner: hälsa, utbildning samt utsatthet för brott. Mer specifikt rör dessa korta översikter risken av att bli utsatt för brott och otrygghet, risken av att drabbas av hjärt- och kärlsjuklighet, och ungdomars studieresultat. Vi är fullt medvetna om att det därutöver finns många 
andra intressanta välfärdsområden som kunde ha redovisats, t.ex. politiska resurser (Strömblad 2003) eller arbetskraftsdeltagande. De tre områden som beskrivs i denna artikel är dock otvivelaktigt viktiga inom segregationsforskningen. De är dessutom olika till sin karaktär vilket betyder att vår genomgång ger en bild av de skilda konsekvenser segregation kan ha för levnadsförhållandena. Vår översikt har fokus på forskningsläget i Sverige.

Innan vi kommer till dessa tre övergripande ämnen för vår artikel finns det skäl att lite närmare diskutera hur några centrala analysredskap och begrepp som segregation och grannskap förhåller sig till varandra.

\section{Segregation och områdeseffekter}

Vad menar man då med boendesegregation, bostadsområde eller grannskap? Med segregation menas allmänt åtskillnad, när vi talar om boendesegregation menar vi att grupper av människor bor åtskilda, där kategoriindelningen oftast bygger på någon form av ekonomiska resurser, etnicitet eller ålder. Även om det inte är självklart hur man geografiskt ska avgränsa det område inom vilket man studerar segregationen kan det allmänt sägas att boendesegregation hänför sig till ett större geografiskt område, oftast en stad eller region, inom vilket man ofta antar att det finns en lokal arbets-, konsumtions- och bostadsmarknad. Inom varje sådant område finns en rad närområden eller grannskap. Inte heller här är det självklart hur sådana skall indelas och hur stort ett grannskap är. I Sverige har det under senare tid blivit vanligt att använda sig av s.k. SAMS (Small Area Market Statistics)-områden som indelningsgrund. SAMS är en rikstäckande indelning av homogena bostadsområden. Graden av boendesegregation kan sägas vara graden av ojämlikhet mellan sådana grannskapsområden. Om ojämlikheten mäts med inkomster, kan segregationen sägas vara den del av den totala ojämlikhet som finns mellan närområden. Om medelinkomster och fördelning av inkomster är identiskt i alla grannskap skulle vi inte ha någon socioekonomisk boendesegregation, om människor utan undantag sorterades till närområden beroende på inkomsterna skulle segregationen vara total.

Orsakerna till segregation är förstås flera men en allmän åtskillnad kan sägas vara den mellan diskriminering och preferenser. Vi kommer här inte närmare att beröra denna fråga men det är för det första värt att notera att även om bostadssegregationen skulle vara helt preferensstyrd kan negativa konsekvenser föreligga. För det andra, i verkligheten är förstås preferenserna villkorliga, även om människor skulle vilja bo i ett visst område är de ekonomiska förutsättningarna kanske inte tillräckliga. När det gäller segregationens konsekvenser har forskningen framförallt fokuserat på de mindre bostadsområden som tillsammans utgör segregationen inom en stad. En vanlig tankegång är då att boendesegregation innebär att vissa områden har en högre ansamling av sociala problem samtidigt som andra kännetecknas av en koncentration av resursstarka individer. Denna ojämlika sammansättning antas skapa olika sociala miljöer/kontexter som i sin tur påverkar

Kölegård Stjärne, Fritzell, Brännström, Estrada \& Nilsson: Boendesegregationens.. 
de boendes välfärd. Det är således effekten av att leva i dessa miljöer som kan kallas en områdeseffekt.

\section{Kontext och komposition}

När områdeseffekter analyseras och diskuteras är det viktigt att klargöra skillnaden mellan kompositions- eller sammansättningseffekter och kontextuella effekter. Om vi påstår att risken att bli utsatt för brott, eller skolprestationerna skiljer sig åt mellan olika bostadsområden förvånar det knappast någon. Om vi rent ekologiskt studerar detta och finner att utfallen i de allra flesta fall är bättre i rika områden än i fattiga kan detta sannolikt till stor del förklaras av att det är just de rika individerna som är friskare, får högre betyg, är mindre utsatta för brott etc. Det är detta som är den kompositionella aspekten. Endast om vi med multivariata tekniker finner att platsen där man bor spelar roll också när vi konstanthåller för individförhållanden bör vi tala om kontextuella effekter. Det vill säga om t.ex. medelinkomsttagare påverkas negativt av att bo i ett fattigt område eller positivt av att bo i ett rikt område. Genom s.k. flernivåmodellering är det numer möjligt att skatta dessa effekter på ett statistiskt mer korrekt sätt. Skiljelinjen mellan komposition och kontext är dock inte så glasklar som det kan verka och det har också ifrågasatts att man överhuvudtaget kan särskilja det som kallats kontextuella effekter från individuella karakteristika (Oakes 2004). Individen skapar sin sociala omgivning men våra livschanser och vägval är samtidigt beroende av vår sociala omgivning.

\section{Varför har området betydelse? Generella förklaringstyper}

Frågan är alltså om platsen där man bor har betydelse för levnadsvillkor. Att ett områdes fysiska utformning kan ha betydelse för upplevelsen av trygghet och att det finns hälsomässiga konsekvenser av nedsmutsning och föroreningar där man bor kan förefalla självklart. Men på vilket sätt kan områdets sociala sammansättning påverka livschanser och välfärd?

Forskningen om områdeseffekter spänner över olika discipliner och synen på vilka mekanismer som är verksamma skiljer sig åt beroende på teoretiskt perspektiv och vilka utfall man studerar. En gemensam nämnare är dock den påverkan som antas ske $i$ det sociala samspelet mellan de boende inom ett område. Här finner vi bland annat teorier (delvis överlappande) om kollektiv socialisation (Wilson 1996), epidemisk normöverföring (Crane 1991), referensgrupper (Festinger 1954), relativ deprivation (Davis 1966), socialt kapital (Coleman 1988), etniskt kapital (Borjas 1991), sociala nätverk (Granovetter 1995), och social desorganisering/kontroll (Shaw \& McKay 1942).

En stor del av denna litteratur handlar om barn och ungdomars utveckling - deras socialisering och karriärvägar - men litteraturen diskuterar även hur vuxna kan påverkas. Resurssvaga bostadsområden - områden med hög arbetslöshet, många fattiga, stor in- och utflyttning, hög andel invandrare och ensamstående föräldrar - antas minska möjligheterna till en framgångsrik socialisering och karriär (t.ex. Elliott et al. 2006). Normer och beteen- 
den formas och förmedlas i vardagliga kontakter med människor i den närmaste omgivningen. Om det är få i ens omgivning som har utbildning och arbete är också de positiva förebilderna färre. I resurssvaga områden antas därför förväntningar och aspirationer på t.ex. utbildning och arbete vara lägre.

Sociala nätverk är en annan förklaring till varför områden med en hög andel arbetslösa kan ge de boende ett sämre utgångsläge på arbetsmarknaden. En förklaring är att man saknar grannar med kontakter $i$ arbetslivet. De som har svaga resurser i olika avseenden kan alltså missgynnas ytterligare av att vara omgivna av andra $i$ samma belägenhet, eftersom det sociala nätverk som står till buds är svagare än det som finns att tillgå i en resursstark omgivning (Lin 1999, Andersson \& van der Burgt 2001). För brottslighet är faktorer som är relaterade till social kontroll centrala. En hög in- och utflyttning liksom stor andel familjer med ensamstående föräldrar är här exempel på faktorer som brukar lyftas fram. Båda dessa antas ha en negativ inverkan på den sociala kontrollen i området (se t.ex. Wikström 1998).

I den mån en kontextuell variabel är aggregerad från en individvariabel brukar man teoretiskt anta att den genererar en effekt i samma riktning som den som gäller på individnivån, men den kan också ha en omvänd effekt. Till exempel öppnar teorin kring relativ deprivation (Runciman 1966) för att en känsla av otillräcklighet kan uppstå om en person med medelutbildning bor i ett område med en stor andel högutbildade vilket, med Jencks och Mayers (1990 s. 117) ord, kan beskrivas som att: »A big frog in a small pond is probably better off than a small frog in a big pond «.

En annan gemensam nämnare i litteraturen är inflytandet av institutionella förhållanden och stigmatisering. Med institutionell påverkan avses ofta kvaliteten och omfattningen av den offentliga/privata servicen i form av skolor, socialtjänst, hälsovård, rekreationsmöjligheter, och så vidare. Den här ansatsen lyfter också fram markanvändningens betydelse, t.ex. hur den fysiska lokaliseringen av skolor, kollektivtrafik, etc. påverkar individers möjligheter till social interaktion (Sampson et al. 2002). En annan källa till påverkan är den lokala möjlighetsstrukturen i form av tillgång till lägenheter, (högre) utbildning och sysselsättning.

Påverkan av stigmatisering, eller stämpling, kan ge upphov till en så kallad adresseffekt (Dean \& Hastings 2000). I de tidigare exemplen om påverkan genom social interaktion inom ett område är de huvudsakliga aktörerna de exkluderade eller marginaliserade invånarna. Genom att peka på betydelsen av de (negativa) mentala föreställningar om "utsatta bostadsområden" som finns hos den övriga befolkningen flyttas här fokus till de exkluderande, eller marginaliserande, krafter som verkar utanför dessa områden. Denna ansats bygger ofta (mer eller mindre tydligt) på teorier kring statistisk diskriminering (se t.ex. Aigner \& Cain 1977). Den övergripande hypotesen är att externa aktörers (t.ex. polis, politiker, media, långivare och arbetsgivare) föreställningar om specifika områden och/eller egenskaper hos dess invånare påverkar invånarnas möjligheter. 


\section{Boendesegregationens förändringar i Sverige}

De kanske två mest genomgripande svenska studierna avseende segregationens mönster och trender är dels Anderssons (2000) studie till Kommittén Välfärdsbokslut, dels de analyser som presenteras i Social Rapport 2006 (Socialstyrelsen 2006). Gemensamt för båda studierna är att de är baserade på totalmaterial, att de tar sitt avstamp 1990 och att de studerar socioekonomisk och etnisk segregation.

Vilka slutsatser kring trender visas då i dessa studier? Andersson menar för det första, i polemik mot storstadsutredningen, att vi inte helt kan reducera den etniska segregationen till en socioekonomisk fråga. Anderson, som datamässigt hade möjlighet att gå fram till 1997/98, menar att det sker en ökning av den socioekonomiska segregationen och att det finns tendenser till att låginkomsttagare kommit att bo mer koncentrerat. Annars är koncentrationen traditionellt högst bland de välbeställda. Andersson finner också att den etniska segregeringen har ökat. I Social Rapport ges en omfattande bild av den etniska och den ekonomiska segregationens utveckling i Sveriges tre storstadsområden fram till år 2002. Den övergripande slutsatsen är att den etniska segregationen ökat markant men inte den ekonomiska. Det hävdas dock samtidigt att den ekonomiska och den etniska dimensionen i högre grad än tidigare blivit överlappande.

\section{Segregationens utveckling 1980-2000}

Som komplement till ovan nämnda studier redovisar vi här nya resultat rörande den socioekonomiska boendesegregationens utveckling i Sveriges 30 största städer 1980, 1990 och år 2000. Vi har med andra ord ett längre tidsperspektiv och ett mer omfattande geografiskt underlag. Vårt primära intresse ligger i de samhälleliga utvecklingsprocesser som skapar större eller mindre ekonomisk homogenitet bland bostadsområden, och vi har här valt att illustrera två olika dimensioner som på lite olika sätt beskriver detta. I den första ansatsen studeras fördelningen av bostadsområdens medelinkomster och vi relaterar spridningen av dessa inkomster till hela inkomstfördelningen, medan den andra fokuserar på ekonomisk resursbrist och beskriver den rumsliga koncentrationen av fattigdom.

Undersökningen baseras på individregister innehållande samtliga personer folkbokförda i Sverige, och omfattar 30 städer med invånarantal på minst 50000 individer. I dessa städer har vi klassificerat bostadsområden utifrån s.k. SAMS-koder. Antalet SAMSområden är 9200 i hela landet. Dessa överensstämmer väl med bostadsområden, det vill säga områden indelade efter hustyp och tydliga avgränsningar i miljön. Efter exklusion av industriområden och områden med färre än 20 vuxna invånare uppgår det totala antalet bostadsområden vid de tre tidpunkterna till 4 622, 4715 och 4 726. Analyserna är baserade på hela den vuxna befolkningen (20 år och däröver) i dessa 30 städer. Vi har valt att basera beräkningarna på disponibel familjeinkomst korrigerat för familjestorlek. 


\section{Segregationens utveckling mätt med Jargowskys Neighbourhood Sorting Index}

För att beskriva skillnader i ekonomiska resurser mellan bostadsområden har vi räknat fram medelvärdet av invånarnas disponibla inkomster inom respektive bostadsområde. Generellt sker en påtaglig ökning av medelinkomsternas spridning inom alla städer under tidsperioden. Tabell 1 visar utvecklingen uttryckt i variationskoefficienter $(\mathrm{CoV})$. CoV är kvoten av standardavvikelsen genom medelvärdet och utrycker således spridningen i resursnivå bland bostadsområden oberoende av medelinkomstnivå. Mätt på detta sätt kan vi se att skillnaderna i inkomstnivå mellan bostadsområden ökar och då i synnerhet i storstadsregionerna.

En del av denna effekt är dock enbart en avspegling av en allmänt ökat inkomstojämlikhet. Det anses ofta att man bör separera dessa olika dimensioner och söka beskriva segregationen skilt från både trender i inkomstnivå och inkomstspridning mellan individer. Ett sätt att göra detta har utvecklats av Jargowsky (1996) i vad som benämns "Neighbourhood Sorting Index" (NSI). Indexet kan anta värden mellan noll och ett och utrycker hur stor andel av en stads totala inkomstojämlikhet som finns mellan bostadsområden. NSI beräknas som kvoten av standardavvikelsen av medelinkomster i bostadsområden dividerat med standardavvikelsen av alla inkomster inom hela staden. Vi tar på detta sätt bort effekten av stadens totala inkomstojämlikhet vid jämförelser över tid och mellan städer. Mer pedagogiskt uttryckt kan man säga att NSI blir ett om alla som bor i ett bostadsområde har identisk inkomst, dvs. all spridning finns mellan områden och noll om alla bostadsområden har identisk medelinkomst.

Som Tabell 2 visar skiljer sig dessa resultat från föregående tabell. Spridningen ökar markant mellan 1980 och 1990 men minskar i de flesta städer mellan 1990 och år 2000. Kan man då säga att segregationen (mätt som variation av bostadsområdens resursnivåer) minskade under 1990 talet? Både ja och nej - den absoluta spridningen av bostadsområdens resursnivåer ökade markant, men ökningen mellan 1990 och 2000 förklaras, i statistisk mening, av den totala ökningen av inkomstojämlikheten $\mathrm{i}$ Sveriges större städer. Det kan vidare noteras att den svenska inkomstspridningen mer allmänt uppvisar något av ett "all-time high" i modern tid just år 2000, vilket möjligen också innebär att den relativa segregering som NSI fångar upp minskar.

\section{Spatial koncentration av fattigdom}

Inom segregationsforskningen har man ofta ett speciellt intresse för fattigdom och speciellt utsatta områden. Också många teorier och hypoteser om segregationens avigsidor koncentrerar sig på fattigdom och på negativa effekter av att fattiga koncentreras till utsatta områden.

Det finns med andra ord skäl att uppmärksamma om den spatiala koncentrationen av fattigdom har ökat eller ej. Tekniskt klassas ekonomiskt resurssvaga individer och områden på följande sätt: Som ekonomiskt resurssvaga eller fattiga

Kölegård Stjärne, Fritzell, Brännström, Estrada \& Nilsson: Boendesegregationens.. 
Tabell I.

Segregationens omfattning år 1980, 1990 och 2000 utryckt som variations-koefficienten av medelinkomstnivån i städernas bostadsområden.

\begin{tabular}{|c|c|c|c|}
\hline & 1980 & 1990 & 2000 \\
\hline Stockholm & 0,080 & 0,171 & 0,265 \\
\hline Göteborg & 0,079 & 0,174 & 0,243 \\
\hline Malmö & 0,097 & 0,196 & 0,284 \\
\hline Uppsala & 0,119 & 0,183 & 0,234 \\
\hline Linköping & 0,090 & 0,149 & 0,194 \\
\hline Västerås & 0,084 & 0,155 & 0,212 \\
\hline Örebro & 0,081 & 0,151 & 0,193 \\
\hline Norrköping & 0,063 & 0,128 & 0,157 \\
\hline Helsingborg & 0,054 & 0,131 & 0,200 \\
\hline Jönköping & 0,076 & 0,124 & 0,152 \\
\hline Umeå & 0,099 & 0,118 & 0,176 \\
\hline Lund & 0,090 & 0,123 & 0,173 \\
\hline Borås & 0,068 & $0,|4|$ & 0,171 \\
\hline Sundsvall & 0,091 & 0,100 & 0,124 \\
\hline Gävle & 0,074 & 0,121 & 0,152 \\
\hline Eskilstuna & 0,072 & $0,|4|$ & 0,181 \\
\hline Halmstad & $0,07 \mid$ & 0,133 & 0,186 \\
\hline Karlstad & 0,079 & 0,133 & 0,160 \\
\hline Södertälje & 0,069 & 0,117 & 0,166 \\
\hline Kristianstad & 0,098 & 0,130 & 0,162 \\
\hline Växjö & 0,106 & 0,153 & 0,186 \\
\hline Skellefteå & 0,078 & 0,082 & 0,074 \\
\hline Luleå & 0,094 & 0,134 & 0,172 \\
\hline Karlskrona & 0,092 & 0,094 & 0,120 \\
\hline Kalmar & 0,074 & 0,120 & 0,151 \\
\hline Östersund & 0,089 & 0,091 & 0,094 \\
\hline Örnsköldsvik & 0,089 & 0,093 & 0,106 \\
\hline Falun & 0,072 & 0,062 & 0,085 \\
\hline Trollhättan & 0,067 & 0,138 & 0,164 \\
\hline Varberg & 0,091 & 0,111 & 0,130 \\
\hline $\begin{array}{l}\text { Viktat medelvärde } \\
\text { (95\% konfidensintervall) }\end{array}$ & $\begin{array}{c}0,083 \\
(0,078-0,087)\end{array}$ & $\begin{array}{c}0,154 \\
(0,142-0,165)\end{array}$ & $\begin{array}{c}0,218 \\
(0,197-0,238)\end{array}$ \\
\hline
\end{tabular}

* måttet tar hänsyn till skiftande befolkningsstorlek i bostadsområden 
Tabell 2.

Segregationens omfattning rensat för allmänna trender $i$ städernas inkomstspridning mätt med Jargowskys NSI år 1980, 1990 och 2000.

\begin{tabular}{|c|c|c|c|}
\hline & 1980 & 1990 & 2000 \\
\hline Stockholm & 0,208 & 0,353 & 0,344 \\
\hline Göteborg & 0,218 & 0,390 & $0,37 \mid$ \\
\hline Malmö & 0,257 & 0,432 & 0,402 \\
\hline Uppsala & 0,300 & 0,414 & 0,348 \\
\hline Linköping & 0,247 & 0,354 & 0,303 \\
\hline Västerås & 0,238 & 0,381 & 0,354 \\
\hline Örebro & 0,233 & 0,375 & 0,326 \\
\hline Norrköping & 0,182 & 0,306 & 0,262 \\
\hline Helsingborg & 0,150 & 0,291 & 0,296 \\
\hline Jönköping & 0,223 & 0,293 & 0,265 \\
\hline Umeå & 0,268 & 0,297 & 0,301 \\
\hline Lund & 0,218 & 0,255 & 0,228 \\
\hline Borås & 0,203 & 0,328 & 0,283 \\
\hline Sundsvall & 0,249 & 0,251 & 0,215 \\
\hline Gävle & 0,212 & 0,307 & 0,272 \\
\hline Eskilstuna & 0,214 & 0,356 & 0,314 \\
\hline Halmstad & 0,198 & 0,315 & 0,307 \\
\hline Karlstad & 0,224 & 0,320 & 0,270 \\
\hline Södertälje & 0,197 & 0,271 & 0,261 \\
\hline Kristianstad & 0,270 & 0,323 & 0,275 \\
\hline Växjö & 0,298 & 0,375 & 0,307 \\
\hline Skellefteå & 0,237 & 0,212 & 0,138 \\
\hline Luleå & 0,271 & 0,361 & 0,317 \\
\hline Karlskrona & 0,263 & 0,246 & 0,204 \\
\hline Kalmar & 0,207 & 0,305 & 0,262 \\
\hline Östersund & 0,251 & 0,231 & 0,172 \\
\hline Örnsköldsvik & 0,252 & 0,237 & 0,198 \\
\hline Falun & 0,197 & 0,150 & 0,151 \\
\hline Trollhättan & 0,207 & 0,362 & 0,304 \\
\hline Varberg & 0,258 & 0,277 & 0,218 \\
\hline $\begin{array}{l}\text { Viktat medelvärde } \\
\text { (95\% konfidensintervall) }\end{array}$ & $\begin{array}{c}0,224 \\
(0,2 \mid 4-0,235)\end{array}$ & $\begin{array}{c}0,345 \\
(0,325-0,366)\end{array}$ & $\begin{array}{c}0,321 \\
(0,299-0,342)\end{array}$ \\
\hline
\end{tabular}

* måttet tar hänsyn till skiftande befolkningsstorlek i bostadsområden

Kölegård Stjärne, Fritzell, Brännström, Estrada \& Nilsson: Boendesegregationens.. 
individer definieras de med en ekvivalerad disponibel inkomst som understiger 60 procent av medianinkomsten. Detta är den fattigdomsgräns som förespråkas av EU. Det är förvisso något godtyckligt om vi ska kalla dessa för relativt fattiga, låginkomsthushåll eller för att vara i riskzonen för fattigdom (Atkinson et al. 2002), men vi väljer här för enkelhetens skull att benämna individer med hushållsinkomster under denna gräns för fattiga. Istället för att utgå från medelinkomster klassificerar vi nu bostadsområden efter hur stor andel av befolkningen i dessa som är fattiga. Som icke resurssvaga bostadsområden klassas de 50 procent av alla områden med minst andel fattiga. Som resurssvaga bostadsområden klassas de 40 procent av alla områden med relativt hög andel fattiga. Som mycket resurssvaga bostadsområden klassas de tio procent av alla områden som har högst andel fattiga.

Figur 1 visar fördelningen av fattiga individer över dessa tre områdestyper 1980, 1990 och år 2000. Resultaten visar en generell trend av ökad rumslig polarisering där individer med knappa ekonomiska resurser $i$ allt högre grad är hänvisade till ett boende i en resursfattig miljö. För gruppen fattiga var ökningen av boende i mycket resursfattiga bostadsområden mindre markant mellan 1980 och 1990, medan minskningen av boende i icke resursfattiga områden var påtaglig (från 41 till 26 procent). Mellan 1990 och år 2000 ser vi istället en kraftig ökning av koncentrationen av fattiga till mycket resurssvaga bostadsområden (från 15 till 26 procent), samtidigt som andelen fattiga i icke resursfattiga miljöer fortsätter att minska om än mindre markant.
En delförklaring till dessa markanta förändringar är att befolkningen mer än fördubblats i de tio procent av bostadsområden som vi klassificerat som mycket resurssvaga, där bodde 4,4 procent av befolkningen 1980, 6,5 procent 1990 och 10,6 procent år 2000. Det är dock inte hela förklaringen, vilket visas om vi ser närmre på befolkningsutvecklingen i dessa mycket resurssvaga områden. Figur 2 visar förändringen $i$ befolkningssammansättning $i$ dessa mycket resurssvaga områden. Definitionen för fattig är densamma som tidigare, som medelinkomsttagare räknar vi alla med en disponibel familjeinkomst på $60-150$ procent av medianinkomsten, dvs. en majoritet av befolkningen. De med disponibla inkomster över 150 procent av medianinkomsten klassificeras som ekonomiskt resursstarka individer. Som figuren visar sker ingen större förändring mellan 1980 och 1990. Däremot mellan 1990 och år 2000 krymper medelklassbefolkningen samtidigt som de relativt fattiga ökar sin andel. Sammantaget ger detta en bild av en samhällsutveckling där resurssvaga individer $i$ allt högre utsträckning utestängs från boende i områden utan ekonomiska problem, samtidigt som representationen av medelklassindivider minskar i resurssvaga områden. Med andra ord krymper möjligheterna för en vardaglig interaktion mellan samhällsgrupper. 


\section{Figur I.}

Fördelningen av fattiga individer (ekvivalerad disponibel hushållsinkomst understigande 60 procent av medianen) över olika typer av bostadsområden.

1980

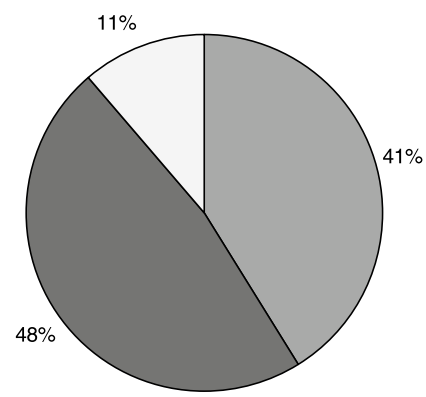

1990

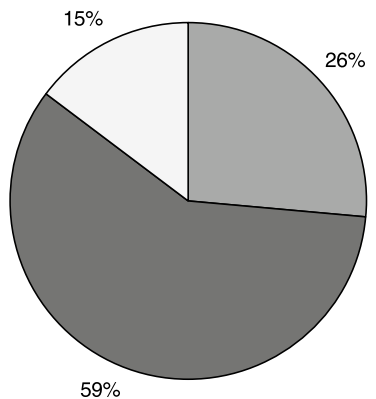

$59 \%$

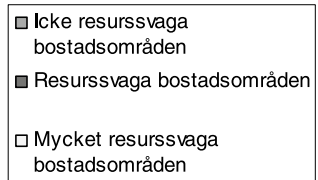

2000

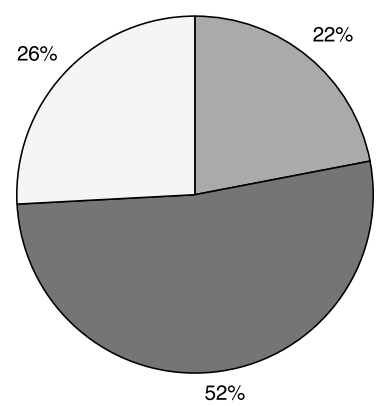

\section{Figur 2.}

Befolkningssammansättning år1980, 1990 och 2000 i de 10 procent av bostadsområden med störst andel relativt fattiga. Som ekonomiskt resurssvaga individer räknas de med en ekvivalerad disponibel hushällsinkomst understigande 60 procent av medianen, som ekonomisk medelklass räknas de med disponibla inkomster på60-150 procent av medianinkomsten, som ekonomiskt resursstarka räknas de med disponibla inkomster över 150 procent av medianinkomsten.

1980

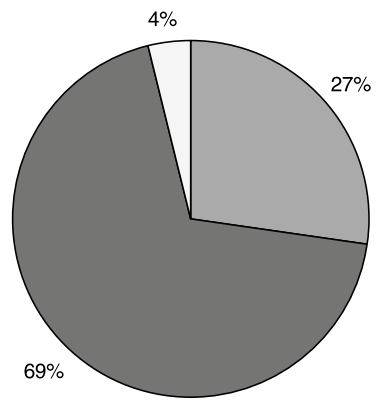

1990

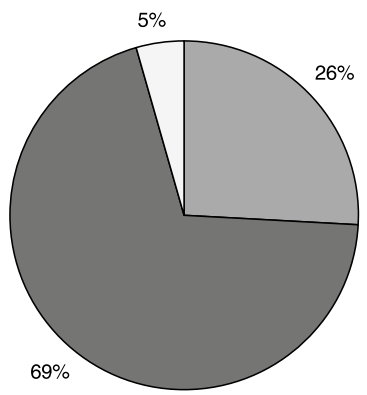

\begin{tabular}{|l|}
$\square$ Ekonomiskt resurssvaga \\
individer \\
$\square$ Individer tillhörande ekonomisk \\
medelklass \\
$\square$ Ekonomiskt resursstarka \\
individer
\end{tabular}

2000

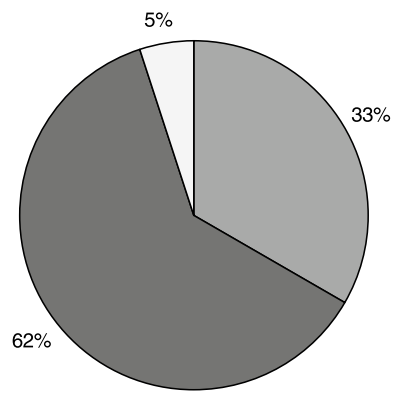

Kölegård Stjärne, Fritzell, Brännström, Estrada \& Nilsson: Boendesegregationens.. 


\section{Grannskapseffekter: Exemplen brott, hälsa och utbildning}

\section{Utsatthet för brott och otrygghet}

Brottslighet och otrygghet får i samhällsdebatten inte sällan utgöra sinnebilden för den resurssvaga förorten. När man ser till brottslighetens geografiska fördelning finner vi variationer mellan stad och landsbygd och mellan bostadsområden i samma stad. Den kriminologiska teori som dominerar vid förklaringar till skillnader i utsatthet mellan olika bostadsområden är social desorganisationsteori (Shaw \& McKay 1942). Enligt denna beror skillnader i utsatthetsrisk på strukturella förhållanden som påverkar områdens informella och formella sociala kontroll. Förhållanden som fattigdom, etnisk heterogenitet och stor in- och utflyttning antas leda till en försvagad social kontroll i området och därigenom en ökad brottslighet. Det har skett en teoriutveckling inom denna tradition där socialt kapital framstår som ett nyckelbegrepp (Sampson et al. 1997, Putnam 2000). Avsaknad av nätverk och tillit mellan de boende samt dåligt fungerande samhällsinstitutioner som människor kan verka genom, antas leda fram till en ogynnsam situation där engagemanget för det egna området minskar. Detta är i sin tur negativt för upprätthållandet av den informella sociala kontrollen.

Ett exempel på en svensk studie av områdesskillnader i brottslighet är Wikströms (1991) studie av utsatthet för brott i åtta förorter i Stockholm. I undersökningen valdes åtta områden ut som tydligt skilde sig åt i befolkningssammansättning och socioekonomiska resurser. Wikström (1991) konstaterar att utsattheten för brott är störst i de områden som har högst andel boende med svaga sociala och ekonomiska resurser och där boendestabiliteten och den sociala integrationen är låg. I regressionsmodeller med kontroll för individvariabler har dock inte områdesförhållanden någon betydelse för utsatthet för våld. Däremot kvarstår en svag områdeseffekt för stöld- och skadegörelsebrott. Den sammantagna bild som ges är att det finns påtagliga skillnader i utsatthet mellan olika bostadsområden. Individoch hushållsförhållanden har dock större betydelse än områdesförhållanden (se också Dolmén 2002).

Att det finns skillnader i utsatthet och rädsla för brott mellan resurssvaga och resursstarka områden framgår även av en undersökning där frågor om utsatthet för brott i SCBs undersökningar av levnadsförhållanden (ULF) kombinerats med uppgifter om de bostadsområden där de intervjuade bor. Figur 3a och b visar risken för att under de senaste tolv månaderna ha utsatts för våld eller hot i det egna bostadsområdet, stöld eller skadegörelse i anslutning till bostaden samt rädsla för brott, här definierat som att ha undvikit att gå ut på kvällen pga. rädsla att utsättas för brott. Bostadsområden (SAMS-områden) i städer har delats in i deciler efter resurstillgång. Indelningen har gjorts efter uppgifter om socioekonomiska förhållanden (andel sysselsatta, låginkomsttagare och familjer med socialbidrag), boendestabilitet (inoch utflytningar samt andel nyinflyttade 


\section{Figur 3.}

Relativa skillnader, oddskvoter, för att under de senaste 12 månaderna ha blivit utsatt för vaild eller hot $i$ det egna bostadsområdet, bostadsrelaterat egendomsbrott respektive avstät från att gå ut på kvällen pga. rädsla för brott. Efter bostadsområdets resurser. Referenskategori resursstarka områden, decil $1(D 1)=1,0)$. Figur 3 a med kontroll för region och områdets befolkningstäthet, Figur 36 även kontroll för individens kön, ålder, födelseland, familjestatus, bostadstyp och förekomst av ekonomiska problem.

a)

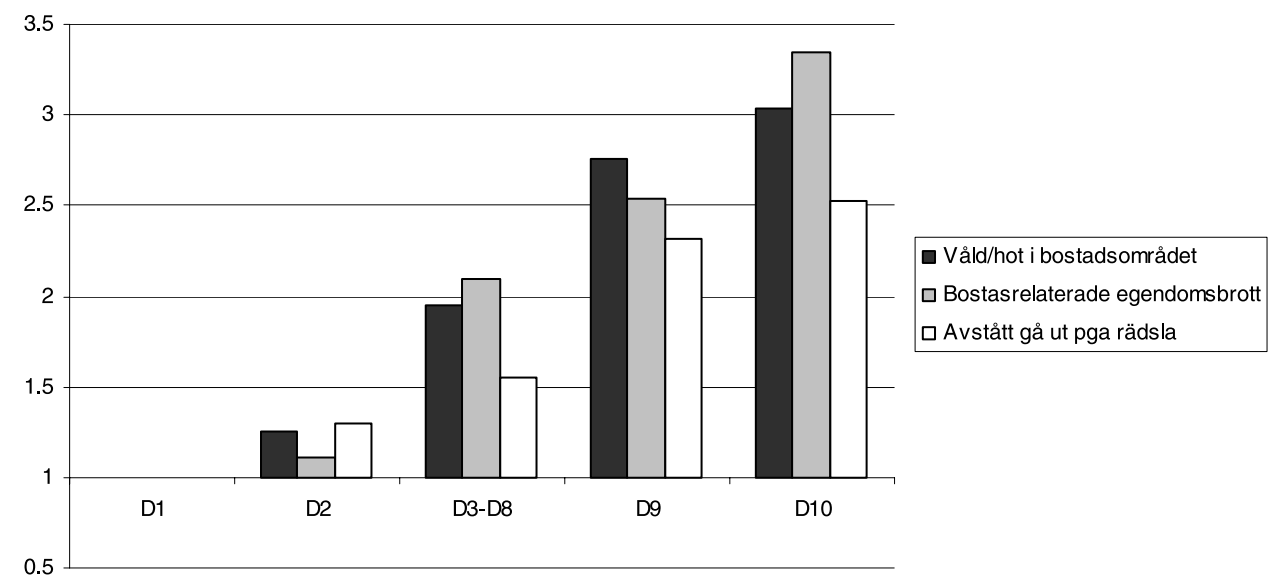

b)

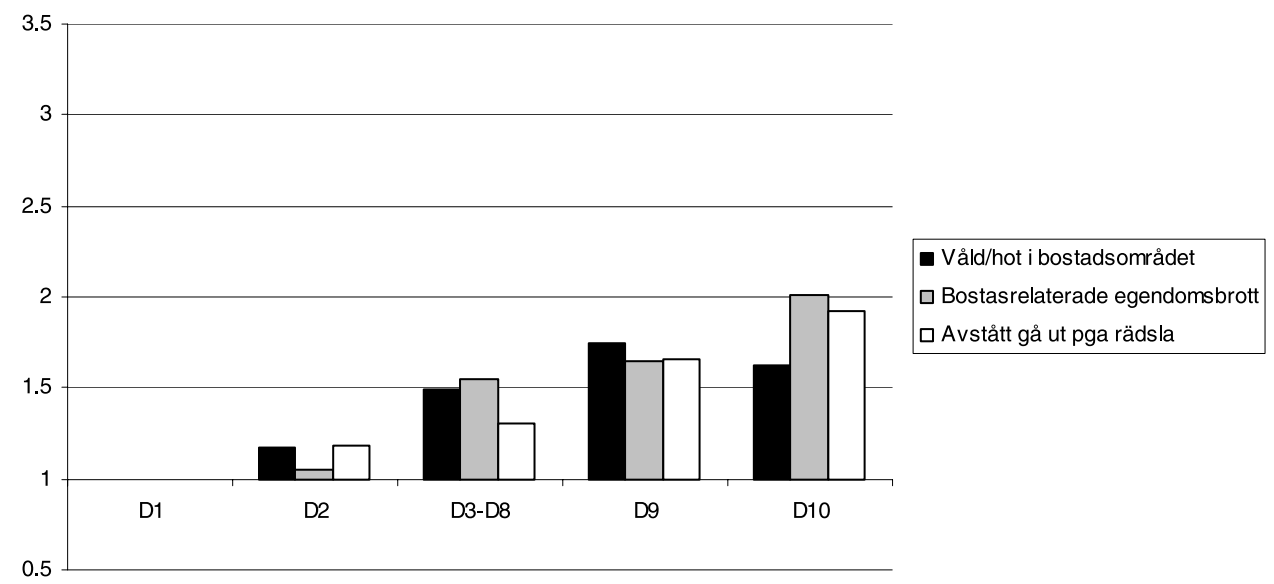

Kölegård Stjärne, Fritzell, Brännström, Estrada \& Nilsson: Boendesegregationens.. 
invandrare), befolkningens utbildningsnivå (andel lågutbildade) samt politiska resurser (valdeltagande). I figuren skiljer vi på dem som bor i de tio procent mest respektive minst resurssvaga bostadsområdena samt de som bor i de 60 procent områden som ligger närmast genomsnittet. (För en närmare beskrivning, se Estrada \& Nilsson 2006, Nilsson \& Estrada 2007).

Vi finner tydliga skillnader i risk både för utsatthet och otrygghet. I de mest resurssvaga områdena (D10) är risken för utsatthet och otrygghet ungefär tre gånger så stor som i de mest resursstarka områdena (D1). De skillnader vi kan se i Figur 3a återspeglar emellertid också skillnader mellan områdena beträffande de intervjuades hushållstyp, ålder, födelseland, ekonomiska resurser etc. Faktorer som på individnivå har samband med utsatthetsrisk och otrygghet. En bidragande förklaring till den högre andelen utsatta i resurssvaga områden är alltså att det i dessa områden bor förhållandevis fler individer med högre individuell risk för utsatthet, dvs. det vi tidigare kalllade en kompositionseffekt. Men kvarstår då skillnaderna i utsatthetsrisk även efter kontroll för dessa individuella faktorer? När vi tar hänsyn till individ- och hushållsförhållanden reduceras skillnaderna mellan resurssvaga och resursstarka områden markant, vilket framgår av Figur 3b. För stöldbrott finner vi dock en viss områdeseffekt för bostadsrelaterade brott. Men detta först då vi jämför extremerna, dvs. de mest resursstarka och de mest resurssvaga områdena. Efter kontroll för individuella faktorer finner vi även en skillnad i rädsla för brott. När det gäller risk att utsättas för våld kvarstår däremot inga signifikanta skillnader efter kontroll för individ och hushållsfaktorer. Här bör det även påtalas att det våld som sker i bostadsområdet endast utgör en mindre del av de våldshändelser som människor utsätts för. Vidare att det våld som förekommer $i$ bostadsområdet $i$ stor utsträckning sker i den egna bostaden. I Figur 3a och $b$ är det just det våld för vilket vi framförallt bör förvänta oss områdeseffekter vi studerat, dvs. det våld som inträffat i det egna bostadsområdet och utanför det egna hemmet. Detta våld utgör cirka tio procent av samtliga våldshändelser som rapporterats i ULF vilket sammantaget talar för att utsatthet för våld endast i mindre utsträckning kan relateras till förhållanden i bostadsområdet. Slutsatsen blir därför att vi inte kan se några områdeseffekter för våldsbrottslighet. De skillnader vi initialt kan se i andel utsatta mellan olika områden beror alltså till största del på selektion (se vidare Nilsson \& Estrada 2007).

Givet den koppling som görs i samhällsdebatten mellan resurssvaga bostadsområden och brott menar vi att detta är resultat som väcker intressanta frågor. I regeringens storstadspolitiska proposition (1997/98:165) görs en tydlig koppling mellan brottslighet och segregation:

"Hög brottslighet och otrygghet $i$ ett område följer hand $i$ hand med en ökad omflyttning av invånarna, vilket starkt motverkar eventuella försök att skapa en känsla av delaktighet och social stabilitet. De som har ekonomiska och andra möjligheter flyttar därifrain och området kommer efterhand att domineras av resurssvaga människor med olika slags sociala problem."(ibid. s. 22) 
Liknande beskrivningar av en neråtgående spiral är vanliga i den internationella forskningslitteraturen (se t.ex. Wilson 1987, Hope 2001) och det finns all anledning att vara uppmärksam på en sådan negativ utveckling. En fråga som dock bör ställas är huruvida det är den faktiska brottsligheten som ska pekas ut som den centrala mekanism som ökar segregationen. En individ som flyttar från ett flerfamiljshus beläget $\mathrm{i}$ ett av de resurssvagaste bostadsområdena i Sverige, till ett flerfamiljshus i ett genomsnittligt område kommer inte påtagligt minska sin risk för utsatthet för brott. Som vi nämnde i tidigare teoriavsnitt styrs människors uppfattning av hur mycket brott och skadegörelse det finns i ett bostadsområde delvis av vilka människor som lever där. En amerikansk studie har med hjälp av enkäter, polisdata samt systematisk observation av bostadsområden visat att koncentration av minoritetsgrupper och fattiga leder till att dessa områden ses som mer brottsbelastade än vad de faktiskt är (även om de har en högre utsatthetsnivå) (Sampson \& Raudenbush 2004). En viktig slutsats är därför att stigmatiseringen av fattiga områden som oproportionerligt brottsdrabbade i själva verket kan visa sig utgöra en viktig förklaring till ökad segregation, det skulle också kunna vara en del av förklaringen till de skillnader vi ser i otrygghet (se vidare Bråmå 2006 om den betydelse områdens "rykte" har som segregationsskapande mekanism).

\section{Hälsa och område}

Huruvida hälsan påverkas av platsen där man bor är idag en central fråga inom forsk- ning kring sociala bestämningsfaktorer till hälsa och hälsoojämlikhet. Anledningarna till att området, eller den sociala kontexten, åter har kommit att stå i fokus är säkert flera men ett viktigt inslag är den uppsjö av studier och diskussioner som emanerade från Wilkinsons $(1992,1996)$ studier kring sambandet mellan inkomstfördelning och folkhälsa. Studierna av områdeseffekter gäller dock normalt inte den nationella nivån utan sambandet mellan förhållanden i bostadsområden och olika hälsoutfall (för översikter se Pickett \& Pearl 2001, Sampson et al. 2002, Macintyre \& Ellaway 2003, för en svensk översiktlig bok i ämnet se Melinder \& Schaerström 2005).

Vad är det då för egenskaper i bostadsområdet som kan påverka hälsan och hur? Fysiska och sociala egenskaper i ett grannskap antas kunna orsaka ohälsa eller verka hälsofrämjande, antingen direkt eller genom de möjligheter människor ges att leva hälsosamma liv. I den folkhälsovetenskapliga litteraturen skiljer man ofta på materiella, infrastrukturella resurser och den kollektiva sociala funktionen. Till materiella, infrastrukturella resurser (som också benämns som möjlighetsstrukturer) räknas t.ex. kvalitet och omfattning av offentlig/ privat service men även luftföroreningar och andra hälsomiljöaspekter i hemmet och dess närmaste omgivning. Med kollektiv social funktion menas t.ex. socialt kapital med tillit och socialt deltagande som ingående komponenter, grad av social integration men även normer och värderingar (Macintyre \& Ellaway 2003, se även Sampson et al. 2002). Det förefaller också rimligt att tro att många materiella och sociala förklaringsfaktorer kan verka samtidigt. 
För att exemplifiera vilka effekter egenskaper i bostadsområdet kan ha på hälsan kommer vi här att fokusera på hjärt-kärlsjuklighet. Hjärt-kärlsjukdomar orsakar flest förtida dödsfall i Sverige i dag och har också en tydlig social gradient. Sjukligheten har dessutom stor geografisk variation (Hammar et al. 2001) som genererat ett flertal hypoteser rörande orsaker och mekanismer. Miljöexponeringar som luftföroreningar, buller och dricksvattenkvalité har studerats (Rosenlund 2005) men också regionala skillnader i hälso- och sjukvårdssystemet som reaktion på skillnader i sannolikheten att överleva en infarkt (Köster et al. 2003, Merlo et al. 2005, Ahlbom et al. 2005). Sedan resultat från ekologiska studier pekat på en positiv korrelation mellan hjärtkärldödlighet och ett områdes socioekonomiska status (Malmström et al. 1999) har ett fält av forskning växt fram som söker belysa sociala determinanter på både områdes- och individnivå och kopplingar däremellan med hjälp av flernivåansatser.

Om nu mer strukturella faktorer av det slag som nämndes ovan ska påverka risken för hjärtinfarkt måste det givetvis till stor del ske genom en rad riskfaktorer som kausalt ligger närmare händelsen. I detta fall vet vi att livsstilsrelaterade faktorer som fysisk aktivitet, kost och rökning är centrala, liksom kronisk stress. Dessa riskfaktorer påverkar i sin tur biologiska riskfaktorer såsom blodtryck, BMI, blodfetter, insulinresistens osv. Människors livsstil och stress är dock inte något som finns i ett vakuum, tvärtom är det mycket som talar för att såväl livsstil som stress påverkas av bakomliggande faktorer på områdesnivå. I amerikanska studier har man kunnat koppla graden av fysisk aktivitet hos individer till den fysiska utformningen av boendemiljön och tillgång till rekreations- och fritidsområden (Humpel et al. 2002). Vidare har tillgången till hälsosam mat visat sig vara sämre i fattiga bostadsområden (Horowitz et al. 2004) samtidigt som vi vet att vår smak och preferens gällande livsstil påverkas av människor i vår omgivning. Både fysisk inaktivitet och en ohälsosam diet är betydande riskfaktorer för insulinresistens, som i sin tur är en riskmarkör för hjärtkärlsjuklighet och ett förstadium till typ 2 diabetes. Detta skulle alltså kunna vara en av de mekanismer som knyter områdesegenskaper till risk för hjärtinfarktsinsjuknande. I ett par studier från USA har man också påvisat samband mellan ekonomisk resursnivå i bostadsområdet och förekomst av insulinresistens (Auchincloss et al. 2007).

I svenska studier av orsaker bakom ett förstagångsinsjuknande i hjärtinfarkt har sociala faktorer på såväl individ som områdesnivå studerats. I en studie (Stjärne et al. 2004) klassificerades alla bostadsområden i Storstockholm efter graden av materiell deprivation (ett index utvecklat av Townsend et al. 1988). Här visades att risken att insjukna i hjärtinfarkt var signifikant högre bland såväl män och kvinnor som bodde $i$ materiellt utsatta områden, något som inte helt förklarades av individernas egna socioekonomiska position eller mer kända närliggande riskfaktorer som blodtryck eller rökning. I en annan studie fokuserades på områdets genomsnittliga inkomstnivå och också här kvarstod signifikanta överrisker av att leva i resursfattiga områden efter kontroll för socioekonomiska variabler på individ- och hushållsnivå (Stjärne et 
al. 2006). Som visas i Figur 4 har män som bor i resursfattiga områden en fördubblad risk att insjukna i hjärtinfarkt jämfört med personer som lever i välbeställda områden.

\section{Figur 4.}

Relativa skillnader, oddskvoter med 95\% konfidensintervall, för att insjukna i hjärtinfarkt efter bostadsområdets socioekonomiska nivå. Den vänstra stapeln anger relativa odds (referenskategori välbeställda områden $\mathrm{Q} 1=1,0)$ kontrollerat för ålder, medan den högra stapeln anger oddsen kontrollerat för ålder, utbildning, social klass och familjestatus.

a) Män

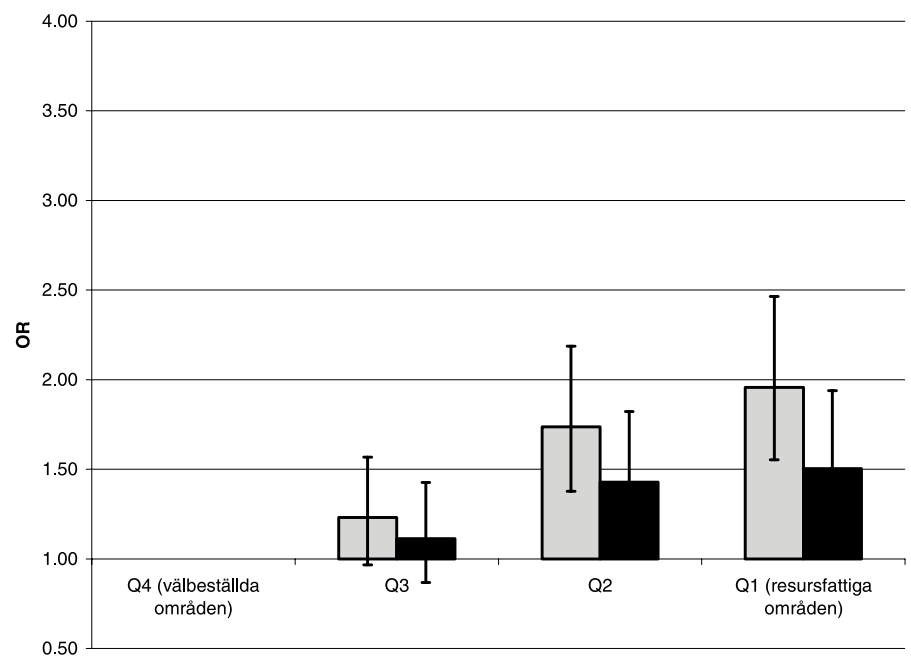

b) Kvinnor

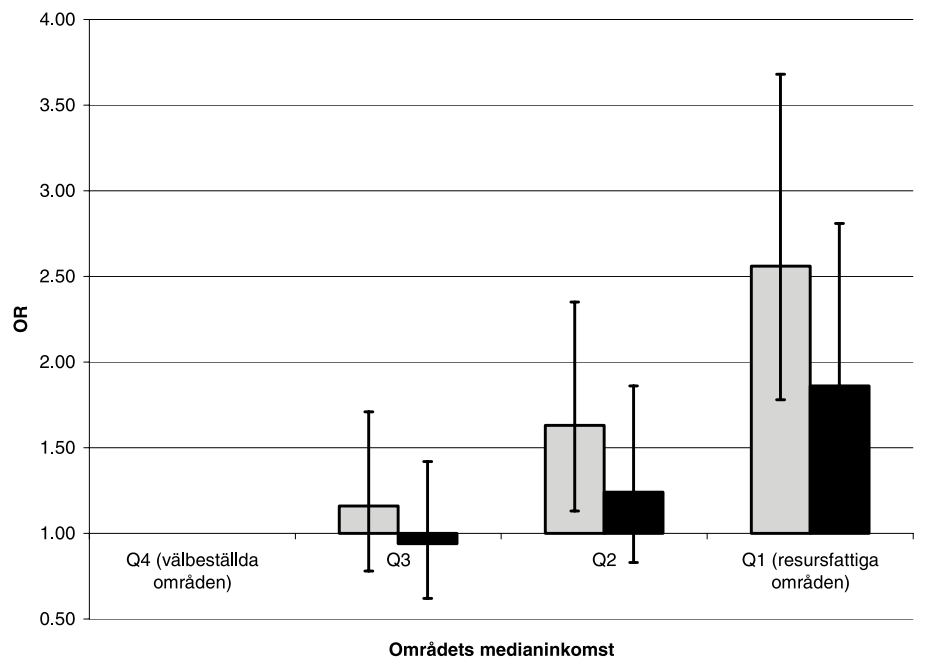

Kölegård Stjärne, Fritzell, Brännström, Estrada \& Nilsson: Boendesegregationens.. 
Denna överrisk sjunker ungefär till hälften när vi kontrollerar för individegenskaper (utbildning, klass och familjestatus). Mönstret för kvinnor är detsamma även om överrisken i sig är något större. I en ny studie från Skåne påvisas att både materiella och sociala områdesegenskaper inte bara påverkar insjuknande utan även risken att inte överleva givet insjuknande (Chaix et al. 2007).

Även om det är viktigt att komma ihåg att studier som dessa egentligen inte undersöker vilka förklaringsfaktorer eller mer närliggande mekanismer som är verksamma, tycks slutsatserna från de flesta studier som analyserat områdets betydelse vara att egenskaper kopplade till socioekonomiska resurser utanför individen är av betydelse för hälsorisker av olika slag. Med reservation för metodologiska problem tycks dessa områdesskillnader inte tillfullo kunna förklaras av individuella karakteristika.

\section{Skola, bostadsområde och studieresultat}

Ett annat område där det är rimligt att förvänta sig effekter av bostadsområdens men kanske framförallt skolors sociala sammansättning är barn och ungdomars studieresultat (för översikter av forskningsfältet, se Jencks \& Mayer 1990, Sheerens \& Bosker 1997). Ett grundläggande tema inom både skol- och bostadsområdesforskning är hur den sociala sammansättningen i dessa miljöer kan påverka ungas preferenser och beteenden (Kirk 2006). Om än på olika sätt är skolan och bostadsområdet betydelsefulla socialisationsmiljöer där barn och ungdomar vistas merparten utav sin vardag. Det finns dessutom påfallande likheter i de processer som påverkar att barn och ungdomar selekteras till olika skolor och bostadsområden. Till exempel är det ofta samma bakgrundsfaktorer som påverkar selektionen in i skola/område och de ungas studieresultat (t.ex. föräldrarnas socio-ekonomiska status). Även om institutionella faktorer (t.ex. skolans ekonomiska resurser, arbetssätt, lärartäthet, etc.) och stigmatiseringsprocesser anses ha betydelse för ungas intressen, aspirationer, utbildningsplaner och därmed studieresultat har forskningen främst uppmärksammat kontakter med "signifikanta andra" i form av grannar och skolkamrater.

Hur kan då kontakter med signifikanta andra i skola och bostadsområde påverka ungas studieresultat? En förklaring är att dessa påverkar ungas preferenser och beteenden genom att fungera som förebilder. Enligt denna ansats baserar en individ sina beslut inte bara utifrån sina egna preferenser utan också utifrån de preferenser och beteenden som gäller i individens referensgrupp. I den socialpsykologiska litteraturen går det att hitta åtskilliga belägg för förekomsten av denna typ av interaktionseffekt, såväl positiva som negativa (t.ex. Brown et al. 1986). En annan förklaring anses vara det sociala nätverkets betydelse. Ungdomars sociala nätverk kan fungera som en viktig resurs där personliga kontakter kan ge ökade chanser till att få information och stöd inför olika handlingsalternativ. Som Szulkin (2006) mycket riktigt påpekar kan förekomsten av denna typ av interaktionseffekter leda till att ungas sociala bakgrund och den sociala sammansättningen i skola 
och bostadsområde samverkar i en process där sambandet mellan ursprung och utbildningsresultat reproduceras till nya generationer.

När ungas sociala omgivning i skola och/ eller bostadsområde omfattar individer med en mindre gynnsam social bakgrund är det rimligt att anta att effekter (som ligger utöver föräldrapåverkan) till följd av social interaktion mellan dessa individer kan uppstå. Utifrån resonemangen om inflytande från signifikanta andra är det således rimligt att förvänta sig ett negativt samband mellan en högre koncentration av resurssvaga individer och ungas studieresultat. I resurssvagare miljöer förmedlas inte tillräcklig kunskap om utbildningssystemet och möjliga karriärer på arbetsmarknaden vilket kan leda till en lägre aspirationsnivå som i sin tur påverkar studieresultaten negativt. I den utsträckning som invandrare tenderar att tillhöra resurssvagare hushåll kan vi även förvänta oss ett negativt samband mellan koncentration av invandrare och studieresultat. Detta borde särskilt gälla för koncentration av första generationens invandrare då dessa (i genomsnitt) förväntas ha sämre kunskaper i det svenska språket. Eftersom effekter av den sociala omgivningen också kan vara positiv kan vi förvänta oss ett positivt samband mellan en högre koncentration av resursstarka individer och ungas studieresultat.

Resonemanget ovan bygger på antagandet att en kontextuell variabel genererar en effekt i samma riktning som den variabel på individnivå den är aggregerad ifrån. Men en kontextuell variabel kan också ha en omvänd effekt. Till exempel kan teorier om relativ deprivation användas för att pre- dicera att en högre koncentration av resursstarka individer för vissa ungdomar kan ge upphov till minskat självförtroende och ökat missmod och därigenom ha en negativ inverkan på studieresultat. I den internationella litteraturen finns det flera exempel på förekomsten av denna typ av omvänd effekt (Davis 1966, Marsh \& Hau 2003).

Vilka slutsatser kan då dras från den svenska forskningen? En enkel genomgång ger vid handen att det finns ytterst få publicerade studier där effekter av skola och bostadsområde på studieresultat har studerats inom ramen för en och samma analys. Merparten av tidigare svenska studier har antingen studerat effekter av den sociala sammansättningen i skola (Erikson 1994, Dryler 1998, Skolverket 2005, 2006, Szulkin 2006, Szulkin \& Jonsson 2007) eller bostadsområde (Rephann 2002, Brännström 2004, Andersson \& Subramanian 2006, Grönqvist 2006). Resultaten från tidigare studier är inte heller entydiga, bland annat beroende på att riktningen på de förväntade effekterna av den sociala sammansättningen i skola och bostadsområde tycks se olika ut beroende på vilket utfall som studeras. Förekomsten av så kalllade statistiska interaktionseffekter, där det t.ex. kan visa sig att flickors men inte pojkars slutbetyg i årskurs 9 påverkas positivt av en högre koncentration av resursstarka individer i skolan (Szulkin 2006), gör det än svårare att dra ur essensen ur tidigare forskning.

Spretigheten i resultaten kan till viss del tillskrivas skillnader i teoretisk ansats, olika datamaterial, tidsepoker, undersökningsdesign, geografisk skalnivå för bostadsområdet, operationaliseringar av skolans och 
bostadsområdets sociala sammansättning, använd analysteknik och utfall. En slutsats man dock kan dra av tidigare svensk (och internationell) forskning är att det i huvudsak är individuella egenskaper och hemförhållanden som påverkar ungas studieresultat (Erikson 1994, Duncan et al. 2001). Ett annat väletablerat faktum är att variationen i studieresultat är betydligt större inom skolor/bostadsområden än mellan dessa enheter. Likaså att det är den sociodemografiska selektionen som till allra största del förklarar varför vi på aggregerad nivå observerar skillnader i studieresultat mellan skolor och bostadsområden.

Men oklarheten i tidigare svensk forskning kan också bero på att effekter av skolans och bostadsområdets sociala sammansättning på studieresultat oftast har analyserats var för sig. Kvarstår till exempel effekten av den sociala sammansättningen i bostadsområdet om man kontrollerar för egenskaper relaterade till skolans sociala sammansättning? I den utsträckning som unga från samma bostadsområde inte nödvändigtvis går i samma skola, och att såväl grund-som gymnasieskolor oftast har elever från flera bostadsområden, blir denna typ av fråga allt viktigare att beakta. En anledning till att sådana analyser är eftersatta beror på att det har saknats relevanta data som innehåller information om både vilken skolenhet och vilket bostadsområde ungdomarna tillhör. På senare år har dock tillgången på denna typ av data ökat vilket har medfört att analyser av detta slag har blivit möjliga att genomföra.

En studie som inom ramen för en och samma analys hanterar både skol- och bostadsområdesdimensionen (här mätt som SAMS-område) är Brännström (2007). Denna studie, som med hjälp av flernivåanalys analyserar påverkan av koncentrationen av resursstarka/-svaga och invandrartäthet på slutbetyget i gymnasiet, visar att variationen i elevernas slutbetyg mellan skolor var ungefär sju gånger större än variationen mellan bostadsområden. Det kunde också påvisas att mer än 60 procent av den variation som initialt tillskrevs egenskaper knutna till bostadsområden fångades upp av egenskaper relaterade till skolan. När det gäller egenskaper relaterade till skolan visade det sig (bland annat) att det (allt annat lika) fanns en statistiskt säkerställd negativ effekt på betyget av att vara första generationens invandrare i en skola med en högre koncentration av resursstarka individer. När det gäller egenskaper relaterade till bostadsområdesnivån visade det sig att det (allt annat lika) fanns en statistiskt säkerställd negativ effekt av att vara första eller andra generationens invandrare och bo i ett område med en högre koncentration av resurssvaga individer.

Även om denna studie har sina begränsningar pekar den dock på att effekter av den sociala sammansättningen i skola och bostadsområde på ungas studieresultat är mycket komplexa och att dessa lämpligen studeras inom ramen för en och samma analys.

\section{Sammanfattande diskussion}

Vi har i denna artikel genom resultat från nya analyser belyst den socioekonomiska boendesegregationen med fokus på den svenska utvecklingen under de senaste 
decennierna. Vi har också sökt belysa de teorier och mekanismer som använts $i$ forskningslitteraturen kring varför och hur segregation och bostadsområde kan påverka individuella välfärdsutfall. Forskningen kring segregationens eventuella effekter har i praktiken i all huvudsak fokuserat på relationen mellan bostadsområdet och välfärdsförhållanden. Med fokus på svensk forskning har vi exemplifierat med resultat kring hur den socioekonomiska strukturen i bostadsområdet är relaterad till tre välfärdsdimensioner, nämligen utsatthet för brott, risken för hjärtinfarkt och skolprestationer.

Även om specifika utfall fordrar specifika mekanismer har vi i teorigenomgången visat att många teoriansatser är gemensamma. Allmänt kan vi för det första separera effekter som kan tänkas uppkomma genom mellanmänskliga relationer. Det kan gälla dels hur vi som individer påverkas av signifikanta andra i området och som kan påverka både risken att begå och bli utsatt för brott, att anamma livsstilar och beteenden som anses hälsovådliga eller påverka vilka utbildningsaspirationer barn och ungdomar (och deras föräldrar) har. En annan typ av förklaringar som ofta använts i litteraturen fokuserar istället på områdets fysiska eller institutionella kvalitet. Det kan här handla om såväl skola som vårdkvalitet. En tredje typ av förklaringsmekanismer som både kan användas för att förklara segregationens utveckling i stort men också varför människor i resursfattiga områden kan diskrimineras rör effekter som härstammar från uppfattningar hos personer utanför dessa områden. Genom en negativ stigmatisering som också kan kallas statis- tisk diskriminering kan människor i dessa områden dels diskrimineras när man exempelvis söker ett arbete och områdets rykte kan i sin tur innebära att mer välbeställda människor undviker att bosätta sig i dessa områden.

Vår analys av den socioekonomiska segregationens utveckling i 30 svenska städer mellan 1980 och 2000 visar tydligt att boendesegregation i Sverige har ökat. Vi studerar detta dels med ett sammanfattande mått som söker renodla och separera segregationens förändringar från allmän ojämlikhetsutveckling, dels genom att visa hur koncentrationen av relativt fattiga personer har ökat betydligt, dels att de som bor i resursfattiga områden $\mathrm{i}$ allt högre utsträckning är ekonomiskt utsatta. De senare analyserna av den spatiala koncentrationen av fattigdom är i mångt och mycket mer alarmerande än våra övergripande analyser av segregationen. Dessa till synes något motstridiga resultat beror på att vi i den övergripande analysen rensar för den allmänna ökningen av inkomstojämlikheten i sig. Den senare analysen visar på en kraftig ökning i de flesta städer mellan 1980 och 1990, medan vårt index i de flesta fall faktiskt pekar på en nedgång mellan 1990 och 2000. Något som dock, som sagt, förklaras av att spridningen i inkomsterna ökat mer än spridningen i bostadsområdenas medelinkomster.

I artikelns tredje del redovisar vi några sammanfattande resultat kring socioekonomiska områdeseffekter. Här visar forskningen, inte oväntat, att individernas egen socioekonomiska position är det som är avgörande. Risken i att utsättas för olika typer av brott är exempelvis mycket 
olika beroende på var vi bor men när vi tar hänsyn till individuella karakteristika försvinner den övervägande delen av dessa skillnader. I huvudsak tycks också detta gälla när vi fokuserar på utbildningsframgångar. Däremot ger våra resultat vid handen att individuella karakteristika inte helt kan utradera de områdeseffekter som tycks existera när vi studerar risken för att insjukna i hjärtinfarkt.

Är då de resultat från flernivåanalyser som vi redovisat skäl att säga att farhågorna för en ökad segregation är överdrivna? Vi tycker det finns flera skäl till att en sådan slutsats är förhastad. För det första, även om flernivåanalyser $\mathrm{i}$ många fall kraftigt reducerar områdeseffekterna kvarstår dessa i många analyser, och i de allra flesta fall tycks de innebära att den socioekonomiska boendesegregationen ökat den befintliga ojämlikheten. Dessutom, även om den negativa områdeseffekten är liten drabbar den många människor. För det andra, en ökad segregation kan ha s.k. tröskeleffekter som visar sig först när ett område har utarmats påtagligt. Med andra ord, vid en viss nivå av social och rumslig isolering av de fattiga uppstår en kvalitativ förändring av området med en mängd negativa konsekvenser som följd; kanske allra mest målande beskrivet av Wilson (1987) i hans inflytelserika bok om hur det amerikanska ghettot förändrade karaktär.

För det tredje är det viktigt att notera en ofta förbigången effekt av den ansats som ofta används i denna forskning. Vi söker renodla effekter av bostadsområdet genom att jämföra olika utfall för personer som bor i olika bostadsområden. På så vis söker man egentligen studera den övergripande segregationens effekter genom den indirekta effekt denna kan tänkas ha på närområdet. Därutöver kan vi mycket väl tänka oss att en ökad segregation inom ett storstadsområde också kan ha direkta effekter. Om exempelvis segregationens ökning skulle leda till en ökad risk för att bli utsatt för brott men att denna ökade risk drabbar alla i staden kommer vi normalt sett inte fånga upp detta i en flernivåanalys av denna enda stad hur noggrant vi än mäter såväl individuella karakteristiska som områdets egenskaper.

Ett fjärde skäl till att ta den ökade socioekonomiska segregationen på allvar är att den på sikt torde utarma möjligheterna att föra en politik som syftar till att begränsa ojämlikheten.

Sammanfattningsvis finns det all anledning att fortsätta uppmärksamma den socioekonomiska boendesegregationens utveckling och också på bästa möjliga sätt söka studera bostadsområdets effekter renodlat eller i kombination med individens sociala position, men även att se till segregationens etniska aspekter. Den etniska segregationen, som vi inte tagit upp i denna artikel, vet vi har ökat markant under den studerade perioden (Socialstyrelsen 2006). Om möjligt bör forskningen också söka studera den vidare segregationens effekter även om detta är än svårare än att söka renodla områdeseffekter. 


\section{Referenser}

Ahlbom A., Alfredsson L., Andersson T., Hallqvist J. \& Strömberg U. (2005) „Fler nivåer, färre skillnader: aktuell analys av sjukhusens vårdresultat kanske ger missvisande bild", Läkartidningen, 102, s. 9-10.

Aigner, D. J. \& Cain, G. G. (1977) "Statistical Theories of Discrimination in Labor Markets", Industrial and Labor Relations Review, 30, pp. 175-187.

Andersson, E. \& Subramanian, S. V. (2006) „Explorations of Neighborhood and Educational Outcomes for Young Swedes", Urban Studies, 43, pp. 2013-2025.

Andersson, R. (2000) „Etnisk och socioekonomisk segregation i Sverige 1990-1998«. I J. Fritzell (red.) Välfärdens förutsättningar, SOU 2000:37. Stockholm: Fritzes.

Andersson, R. \& van der Burgt, D. (2001) Segregationens konsekvenser. Litteraturöversikt och diskussion av forskningsläget. IM-gruppen i Uppsala för Social rapport 2001.

Atkinson T., Cantillon B., Marlie E. \& Nolan B. (2002) Social Indicators. The EU and Social Inclusion. Oxford: Oxford University Press.

Auchincloss H., Diez Roux A., Brown D., O’Meara E. \& Raghunathan T. (2007) "Association of Insulin Resistance with Distance to Wealthy Areas: The Multi-Ethnic Study of Atherosclerosis", Am. J. Epidemiol. 165, pp. 389-397.

Berglind, H. (1974) "Segregationsprocesser i dagens samhälle». I Å. Daun et al (red.), Samhällsförändringar och brottslighet. Stockholm: Tidens förlag.

Borjas, G. J. (1991) „Ethnic Capital and Intergenerational Mobility", Quarterly Journal of Economics, 107, pp. 123-150.

Brown B., Clasen D. \& Eicher S. (1986) „Perceptions of Peer Pressure, Peer Conformity Dispositions, and Self-Reported Behavior among Adolescents", Developmental Psychology, 22, pp. 521-530.

Bråmå, Å. (2006) Studies in the Dynamics of residential segregation. Uppsala: Department of Social and Economic Geography.
Brännström, L. (2004) „Poor Places, Poor Prospects? Counterfactual Models of Neighbourhood Effects on Social Exclusion in Stockholm, Sweden", Urban Studies, 41, pp. 2515-2537.

Brännström, L. (2006) Phantom of the Neighbourhood. Longitudinal Studies on Area-based Conditions and Individual Outcomes. Stockholm: Swedish Institute for Social Research.

Brännström, L. (2007) "Making Their Mark: Disentangling the Effects of Neighbourhood and School Environments on Educational Achievement». Working Paper 2007:3. Stockholm: Institute for Futures Studies.

Buck, N. (2001) "Dentifying neighbourhood effects on social exclusion", Urban Studies, 38, pp. 2251-2275.

Chaix B., Rosvall M. \& Merlo J. (2007) „Neighborhood socioeconomic deprivation and residential instability“, Epidemiology, 18, pp. 104-111.

Coleman, J. S. (1988) "Social capital in the creation of human capital", American Journal of Sociology, 94, pp. 95-120.

Crane, J. (1991) »The Epidemic Theory of Ghettos and Neighborhood Effects on Dropping Out and Teenage Childbearing", American Journal of Sociology, 96, pp. 1226-1256.

Davis, J. A. (1966) »The Campus as a Frog Pond", American Journal of Sociology, 72, pp. 17-31.

Dean, J. \& Hastings, A. (2000) Challenging Images: Housing Estates, Stigma and Regeneration. Bristol: The Policy Press.

Dolmén, L. (2002) Brottslighetens geografi. Stockholm: Kriminologiska institutionen, Stockholms universitet.

Dryler, H. (1998) Educational Choice in Sweden: Studies on the Importance of Gender and Social Contexts. Stockholm: Swedish Institute for Social Research.

Duncan G. J., Boisjol J. \& Mullan Harris K. (2001) "Sibling, Peer, Neighbor, and Schoolmate Correlations as Indicators of the Importance of Context for Adolescent Development", Demography, 38, pp. 437-447.

Elliott D. S., Menard S., Rankin B., Elliott A.,

Kölegård Stjärne, Fritzell, Brännström, Estrada \& Nilsson: Boendesegregationens.. 
Wilson W. J. \& Huizinga D. (2006) Good Kids from Bad Neighborhoods. Successful Development in Social Context. Cambridge: Cambridge University Press.

Erikson, R. (1994) "Spelar valet av skola någon roll? Effekter av grundskola och omgivning på övergången till gymnasiet». I R. Erikson \& J. O. Jonsson (red.) Sorteringen i skolan. Stockholm: Carlssons.

Estrada, F. \& Nilsson, A. (2006) Segregation och utsatthet för egendomsbrott. Betydelsen av bostadsområdets resurser och individuella riskfaktorer. Rapportserie Institutet för Framtidsstudier 2006:5. Stockholm: Institutet för framtidsstudier.

Festinger, L. (1954) "A Theory of Social Comparativeness", Human Relations, 7, pp. 117-140.

Granovetter, M. S. (1995) Getting a Job: A Study of Contacts and Careers. Chicago: Chicago University Press.

Grönqvist, H. (2006) "Ethnic Enclaves and the Attainments of Immigrant Children", European Sociological Review, 22, pp. 369-382.

Hammar N., Andersson T., Reuterwall C., Nilsson T., Knutsson A. \& Hallqvist J. (2001) „Geographical differences in the incidence of acute myocardial infarction in Sweden. Analyses of possible causes using two parallel case-control studies", J Intern Med, 249 (2), pp.137-144.

Hope, T. (2001) "Crime victimisation and inequality in risk society". I R. Matthews \& J. Pitts (red.) Crime, disorder and community safety. London: Routledge.

Horowitz CR., Colson KA. \& Hebert PL. (2004) "Barriers to buying healthy foods for people with diabetes: evidence of environmental disparities", American Journal of Public Health 94, pp. 1549-1554.

Humpel N., Owen N. \& Leslie E. (2002) „Environmental factors associated with adults' participation in physical activity: a review", Am J Prev Med, 22, pp.188-199.

Jargowsky, P.A. (1996) "Take the money and run: Economic segregation in the U.S. metropolitan areas", American Sociological Review, 61, pp. 984-998.
Jencks, C. \& Mayer, S. (1990) »The Social Consequences of Growing Up in a Poor Neighborhood". I L. Lynn \& M. McGreary (red.) InnerCity Poverty in the United States. Washington, DC: National Academic Press.

Kirk, D. (2006) Unraveling the Neighborhood and School Effects on Youth Behavior. Chicago: Chicago University, Department of Sociology.

Köster M., Andersson J., Carling K. \& Rosén M. (2003) "Dödlighet efter hjärtinfarkt har minskat i nästan alla landsting under 1990-talet: störst förbättringar i de landsting som hade sämst resultat från början“, Läkartidningen, 100 , s. 2838-2844.

Lin, N. (1999) "Social networks and status attainment", Annual Review of Sociology, 25, pp. 467487.

Macintyre, S. \& Ellaway (2003) „Neighbourhoods and health". I I. Kawachi \& L. Berkman (red.) Neighborhoods and Health. Oxford/NY: Oxford University Press.

Malmström M., Sundquist J., Bajekal M. \& Johansson S-E. (1999) »Ten-year trends in all-cause mortality and coronary heart disease mortality in socio-economically diverse neighbourhoods", Public Health, 113, pp. 279-284.

Marsh, H. W. \& Hau, K. T. (2003) „Big-Fish-LittlePond Effect on Academic Self-Concept: A Cross-Cultural Test of the Negative Effects of Academically Selective Schools", American Phychologist, 58, pp. 364-376.

Melinder, K. \& Schaerström, A. (red.) (2005) Platsen, individen och folkhälsan. Stockholm: Folkhälsoinstitutet.

Merlo J., Håkansson A., Beckman A., Lindblad U., Lindström M., Gerdtham U-G. \& Råstam L. (2005) „God vård på lika villkor vid hjärtinfarkt i dagens Sverige: geografiska skillnader i dödlighet utan betydelse för den enskilda patienten", Läkartidningen 102, s. 20-23.

Musterd, S. (2005) „Social and ethnic segregation in Europe: levels, causes, and effects", Journal of Urban Affairs, 27, pp. 331-348.

Nilsson, A. \& Estrada, F. (2007) „Risky neighbourhood or individuals at risk? The significance of neighbourhood conditions for violent victimi- 
sation in residential areas", Journal of Scandinavian Studies in Criminology and Crime Prevention, 8:1, pp. 2-21.

Oakes, M. (2004) »The (Mis)estimation of Neighborhood Effects: Causal Inference for a Practicable Social Epidemiology", Social Science \& Medicine, 58, pp.1929-1952.

Palander, C. (2006) Områdesbaserad politik för minskad segregation. En studie av den svenska storstadspolitiken. Geografiska regionstudier nr. 66. Uppsala: Kulturgeografiska institutionen, Uppsala universitet.

Pickett, K.E. \& Pearl, M. (2001) „Multilevel analyses of neighbourhood socioeconomic context and health outcomes: a critical review", Journal of Epidemiology and Community Health, 55, pp. 111-122.

Putnam, R.D. (2000) Bowling alone. New York: Simon \& Schuster

Regeringens proposition. 1997/98:165. Utveckling och rättvisa - en politik för storstaden på 2000-talet.

Rephann, T. J. (2002) »The Importance of Geographical Attributes in Decision to Attend College", Socio-Economic Planning Sciences, 36, pp. 291307.

Rosenlund M. (2005) Environmental Factors in Cardiovascular Disease. Stockholm: Karolinska Institutet.

Runciman, W.G. (1966) Relative Deprivation and Social Justice. London: Routledge \& Kegan Paul.

Sampson R. J., Raudenbush S. \& Earls F. (1997) "Neighbourhoods and violent crime: A multilevel study of collective efficacy", Science, 277, pp. 918-924.

Sampson, R.J. \& Raudenbush, S. (2004) "Seeing disorder: Neighbourhood stigma and the social constructions of broken windows", Social Psychology Quarterly 67, pp. 319-342.

Sampson R.J., Morenoff J.D. \& Gannon-Rowley T. (2002) "Assessing 'neighbourhood effects': Social processes and new directions in research", Annual Review of Sociology, 28, pp. 443-478.

Shaw, C.R. \& McKay, H.D. (1942) Juvenile Delin- quency and Urban Areas. Chicago: The University of Chicago Press.

Sheerens, J. \& Bosker, R. (1997) The Foundations of Educational Effectiveness. Oxford: Elsevier Science.

Skolverket (2005) Om skolors olikheter och dess betydelse för elevernas skolresultat. Rapport 273. Stockholm: Skolverket.

Skolverket (2006) Vad händer med likvärdigheten $i$ Svensk skola? Rapport 275. Stockholm: Skolverket.

Socialstyrelsen (2006) Social Rapport 2006. Stockholm: Socialstyrelsen.

Stjärne, M.K. (2005) A matter of context. Social inequalities in incidence of myocardial infarction. Stockholm: Centre for Health Equity Studies.

Stjärne M.K., Fritzell J., Ponce de Leon A. \& Hallqvist J. (2006) "Neighborhood Socioeconomic Context, Individual Income and Myocardial Infarction", Epidemiology, 17, pp. 14-23.

Stjärne M.K., Ponce de Leon A. \& Hallqvist J. (2004) "Contextual effects of social fragmentation and material deprivation on risk of myocardial infarction", International Journal of Epidemiology, 33, pp. 732-741.

Strömblad, P. (2003) Politik på stadens skuggsida. Uppsala: Acta Universitatis Upsaliensis.

Szulkin, R. (2006) „Den etniska omgivningen och skolresulat - en analys av elever i grundskolan 1998 och 1999", Arbetsmarknad \& Arbetsliv, 12, s. 223-239.

Szulkin, R. \& Jonsson, J. O. (2007) "Immigration, Ethnic Segregation and Educational Outcomes: A Multilevel Analysis of Swedish Comprehensive Schools», SULCIS Working Paper 2007:2. Stockholm: The Stockholm University Linneaus Center for Integration Studies.

Townsend P., Phillimore P. \& Beattie A. (1988) Health and deprivation. London: Croon Helm.

Wikström, P.O. (1991) Sociala problem brott och trygghet. Brå-rapport 1991:5. Stockholm: Brottsförebyggande rådet.

Wikström, P.O. (1998) "Communities and Crime». I M. Tonry (red.) The Handbook of Crime and Punishment. Oxford: Oxford University Press.

Kölegård Stjärne, Fritzell, Brännström, Estrada \& Nilsson: Boendesegregationens.. 
Wilkinson, R.G. (1992) »Income distribution and life expectancy", BMJ, 304, pp. 165-168.

Wilkinson, R.G. (1996) Unhealthy Societies: The Afflictions of Inequality. London: Routledge. Wilson, W. J. (1987) The Truly Disadvantaged.
The Inner City, the Underclass, and Public Policy. Chicago: Chicago University Press.

Wilson, W. J. (1996) When Work Disappears. The World of the New Urban Poor. New York: Alfred A. Knopf.

\section{Summary}

\section{Residential segregation Trends and consequences}

In many countries there is growing concern about the effects of residential segregation. This paper focuses on socio-economic segregation: whether and how neighbourhoods may influence life chances and living conditions. In this article we first present theories and mechanisms that have been used in different research fields in order to understand how the place where you live may influence various outcomes. We make an empirical analysis of how socio-economic segregation has changed in 30 city areas in Sweden from 1980 to 2000. We then give examples from research, focusing on Sweden, within three central fields in which neighbourhood effects have been studied: crime, health and school achievements.

When looking at the literature trying to explain why neighbourhood matters we find that many theoretical approaches and suggested mechanisms are similar across research fields. Generally we can distinguish between explanatory factors drawing on social contacts and interaction between individuals within an area, mechanisms focusing on the social infrastructure within areas and, thirdly, mechanisms of a discriminatory nature originating from attitudes and rumours about the disadvantaged area and its inhabitants.
Our results indeed show that residential socio-economic segregation has increased in Sweden. We find that the poor have become more spatially concentrated to poor neighbourhoods. When reviewing our own and others' research on the risks of being exposed to crime, on cardiovascular disease risks, and on school achievements we no doubt find that the socio-economic characteristics of individuals, rather than areas, are imperative. In other words, controlling for individual characteristics greatly attenuates the area effects. Is, then, the threat of increasing segregation exaggerated? We do not think one should jump to such a conclusion. First, most multi-level analyses show that neighbourhood effects increase inequality. Second, segregation may have serious threshold effects beyond certain levels. Third, neighbourhood analyses are only able to find indirect effects of segregation; if increased segregation leads to negative outcomes for all, irrespective of where you live, it is not seen in analyses of that particular city. Fourth, increasing socio-economic segregation might impoverish political support for policies aiming at reducing inequality more generally. 